vic $w_{3}$ and under various magnifying powers. Aitogether the phenomenon was as distinct as in the case of our moon. On February 3,16 , and 21 it was not seen, but on the evening of February 28 , it was again prominently visible to Harding; the illumination was now of a reddish grev "like that of the moon in a total eclipse." Yet on the same evening Schröter looked in vain for the phenomenon at Lilienthal, showing how cautiously negative evidence should be received.

Observations of the secondary light were made by Pastorff in 1822 and by Gruithuisen in 1825 .

The Monthly Notices of the Royal Astronomical Society contain many observations since the year $\mathbf{1 8 4 2}$ by Messrs. Berry, Browning, Guthrie, Langdon, Noble, Prince, and others. Mr. Prince had favourable views of the illumination of the dark side in September 1863 . Capt. Noble's observations, as remarked by Prof. Winnecke in his notice of Prof. Safarik's memoir, do not appear to refer to the secondary light as it has been perceived by other observers. He mentions that the hemisphere unilluminated by the sun has to him "always appeared distinctly and positively darker than the backround upon which it was projected," a statement which certainly gives the observations a distinctive character.

There are also observations of the secondary light by byman, at Yale College in 1867 , and about the same time by Safarik at Prague, and in August, 1871, more decidedly. In September of the latter year the whole disk of Venus was seen by Prof. Winnecke as described in Ast. Nach., No. 1863. This astronomer has since stated that notwithstanding he has observed the planet many hundred times during the last swenty-four years, he has only succecded in perceiving this remarkable illumination of the dark side on two occasions ; and it should be added that Dawes, Mädler, and other eminent observers, have never detected it. We shall revert to this subject next week.

THE OBSERVATORy at ATHENS.-- The death is announced of Baron Simon von Jina, son of the founder of the Observatory at Athens, which has been successively under the direction of M. Bouris and Herr Julius Schmidt. The deceased Baron is mentioned as a liberal patron of this establishment, though not himself engaged in scientific pursuits, and Herr sichmidt writes doubtfully of the future of the Observatory. Every astronomer will entertain the hope that this most laborious and successful observer-distinguished not only by his great work upon the moon, but for his numerous discoveries and observations of variable stars, his long and important series of observations of comets, of short period and otherwise, in which he has made excellent use of the advantages of his southern position, and many other valuable contributions to observational astronomy-may continue to hold, under fivourable auspices, the direction of an establishment which his exertions have made so honourably known in the astronomical world.

\section{THE LOAN COLLECTION CONFERENCES}

WING to the pressure on our space this week, we can only refer briefly to what has been done since our last notice at the Conferences in connection with the Loan Collection. We give, however, in another part of the paper the presidential addresses of Dr. J. Burdon Sanderson, F.R.S., in the Section of Biology, and of Mr. John Evans, F.R.S., in the comprehensive Section of Physical Geography, Geology, \&c. We hope in early numbers to be able to give at some length the principal papers which have been read in the various sections.

On Thursday last the concluding meeting in the Section of Micchanics was held, when the following papers were read :-_"On Prime Movers," by Mr. Bramwell, F.R.S.; "The Construction of Furnaces", by Mr. Hackney; "A History of Electric Telegraphs," by Mr. Preece.
The first meeting in the Section of Biology was held on Friday, when the papers of which we gave a list in our last week's notice were read. This Section met also on Monday, when the following papers were read :-

Dr. Royston-Pigott, F.R.S., on a "Microscope with Complex Adjustments, Searcher, and Oblique Condenser Apparatus ;" Prof. Ritherford, F.R.S., "On a Freezing Microtome ;" Prof. Flower, F.R.S., "On the Osteological Preparations exhibited by the Royal College of Surgeons ;" Herr Prof. Dr. Donders, "Ophthalmological Apparatus ;" Dr. M'Kendrick, "Acoustical Instruments ;" Prof. Yeo, M.D., and Dr. Urban Pritchard, "On Microtomes."

On Tuesday the first meeting in the Section of Physical Geography, Geology, Mineralogy, and Meteorology, was held, when, in addition to the President's Address, the following papers were read :-

Mr. R. H. Scott, F.R.S., "Meteorological Instruments in the Loan Collertion;" Mr. G. J. Symons, "The Measurement of the Rainfall ;" Dr. R. J. Marn, "Lightning Conductors;" M. le Professeur A. Daubrée, "La Géologie Synthétique;" Mr. J. E. H. Gordon gave an explanation of his Anemometer; Mr. C. O. F..Cator "On Anemometers;" Prof. vnn Oettingen gave a description of his Anemometer; Dr. R. J. Mann, "Lowne's Series of Anemometer's" Mr. John Evans, F.R.S., "Dalton's Percolation Gauge."

This Section meets again to-day and to-morrow, for which days the following programme has been drawn up :For to-day.-Capt. Baron Ferdinand von Wrangell, "On Self-registering Tide-gauges;" Lieut. Cameron, R N., "Physical Geography of South Tropical Africa;" Major Anderson, R.E., "Maps of Palestine ;" Col. Walker, R.E., or Col. Montgomerie, R.E., "Discoveries in Tibet ;" Mr. Francis Galton, F.R.S., "On Means of Combinirg Various Data in Maps and Diagrams ; Capt. Evans, R.N., C.B , F.R.S., Hydrographer of the Navy, "Hydro" graphy, its present Aspects;" Capt. J. E. Davis, R.N., "The various ferms of Sounding Apparatus used by Her Majesty's Ships in ascertaining the depth of the ocean, and the nature of its bottom;" Staff-Commander E. W. Creak, R.N., "Nautical Magnetic Surveys ;" Prof. Roscoe, F.R.S., "Automatic Light Registering Apparatus." For to-morrow.--Prof. Ramsay, F.R.S., "The Origin and Progress of the Geological Survey of the British Isles, and the method on which it is conducted;" Mr. W. Topley, F.G.S., "The Sub-Wealden Boring;" Mr. C. E. de Rance, F.G.S., "Sketch of the Geology of the known Arctic Regions ; "Mr. W. Galloway, "Colliery Explo. sions;" Prof. Baron von Ettingshausen, "The Tertiary Origin of the actual Flora ; "Mr. I. S. Gardner, F.G.S., "The Tertiary Floras;" M. des Cloiseaux, Membre de l'Institut, "L'emploi des propriétés biréfringentes à la détermination des cristaux ; Mr. Walter Rowley, F.G.S, "Description of his Transit Theodolite for Mine Surveying, and other purposes;" The Rev. Nicholas Brady, M.A., "Desirability of a Uniform International Notation for Crystallography."

This will conclude these Conferences, which are admitted on all hands to have been a great success and to have added very much to the practical value of the collection. The popular expositions we referred to last week have been carried on with success, and apparatus may now be minutely inspected on Wednesdays, Thursdays, and Fridays, on application to the Director of the South Kensington Museum on forms provided for the purpose.

As we intimated last week, the Science and Art Department are organising a series of popular lectures in connection with the Loan Collection, to be given on the evenings of the free days-Mondays, Tuesdays, and Saturdays. We believe that the first of these lectures will be given on Saturday by Prof. Roscoe, F.R.S., on. Dalton's Apparatus, and what he did with it." 